\title{
DIGITAL CUSTOMER AS A CREATOR OF THE REPUTATION OF MODERN COMPANIES
}

\author{
Danuta SZWAJCA \\ Silesian University of Technology, Faculty of Organization and Management, Gliwice, POLAND \\ e-mail: danuta.szwajca@polsl.pl
}

\begin{abstract}
Scientific and technical developments and progressive digitization in almost all areas of life have led to the development of a new type of digital customer, with specific requirements and expectations for suppliers of goods and services. Customers, in particular consumers, are one of the key groups of stakeholders who create the corporate reputation. Customers are first of all creators of the corporate reputation as an "offeror" and "supplier" of value to buyers, as well as co-creators of the company's reputation as a market player, employer, business partner or citizen, because their purchase decisions determine the company's ability to meet the expectations of other stakeholder groups, that is, investors, employees or business partners. Building and maintaining a good reputation requires proper identification and satisfaction of the needs of key stakeholder groups. The aim of the article is to identify the specific requirements and expectations of digital customers in the context of building and maintaining a good reputation of the company. The thesis is that the digital customer expects, first and foremost, reliability and personalization in their relations with the supplier.
\end{abstract}

Keywords: digital customer, corporate reputation, reputation management, stakeholders.

JEL: L14, L25, M31.

\section{1}

\section{Introduction $^{1}$}

Dynamic technological progress in the field of information technology and the development of the Internet are leading to a growing digitization that covers new areas of life. With mobile devices that enable connection to the network almost anywhere, and the right applications, one can quickly obtain the necessary information, communicate with multiple recipients, transfer information, settle many issues and solve various problems. The use of devices such as mobile phones, smartphones and laptops is becoming more and more common and permanent, especially among the representatives of $\mathrm{Y}$ and $\mathrm{Z}$ generations (Krzepicka, 2016).

According to the research conducted by the Chamber of Electronic Economy and Mobile Institute in 2015-2018, 8 out of 10 Polish Internet users say they use a mobile device, $50 \%$ of smartphone users use it practically all the time, $18 \%$ of respondents most frequently communicate with their families via Mes-

\footnotetext{
${ }^{1}$ This article was submitted at the 3rd National Scientific Conference DEMIST '19 (DEMIST 2019), Warsaw University of Technology, Warsaw, Poland, May 30, 2019 (https:// 2019.demist.eu/)
}

senger (www1, 2018). Undoubtedly, the widest application of mobile devices and the Internet are in the area of shopping. Year by year, the number of people shopping online and using mobile devices is growing. According to the quoted research, half of the Internet users buy online, more and more often using mobile devices. In 2018, $68 \%$ of respondents declared that they had bought something using a mobile device, compared to $32 \%$ in 2015 and $49 \%$ in 2016. In addition, over $23 \%$ of Internet users shop through mobile applications, 1 in 3 users use mobile banking applications, $25 \%$ of Internet users migrate during the purchase process between a computer and a smartphone. At the same time, 2 out of 3 Internet users consider it important whether a brand/shop is available on a mobile device. Oracle research shows that $78 \%$ of brands are planning to implement virtual reality solutions for customer service by 2020 , and four in five $(80 \%)$ will serve customers through chatbots (www2, 2016).

Mobile technologies are increasingly influencing not only the business environment and shopping habits, but also lifestyle changes and consumer values. A new type of customer and consumer is created, who freely moves in virtual reality, and who is char- 
acterized by a different way of thinking, mentality, sensitivity, aspirations. It is referred to as a digital customer. As the lifestyle and value system of a new type of customer changes, so do the expectations and evaluation criteria of the company, which form the basis for the development of its reputation as a provider of goods and services. Building a good reputation requires analysis of the digital customer's profile in order to meet its new requirements and expectations.

Therefore, the article aims to identify the specific requirements and expectations of a digital customer in the context of building and maintaining a good reputation of the company. The thesis is that the digital customer expects, first and foremost, reliability and personalization in relations, that may be considered the pillars of reputation. Methods of analyzing contemporary reputation concepts and conclusions, based on the analysis of research results of national and international research centers and consulting companies were applied.

\section{Customers/consumers as creators of the company's reputation}

A corporate reputation is an opinion of various stakeholder groups of the company, based on the assessment of various aspects of its activity. It follows from this definition that the originators and creators of the company's reputation are its stakeholders. According to Dowling (2016), it is not really the company that is the "owner" of the reputation the "owners" of the company's reputation are other people, that is, stakeholders. Their needs, requirements and expectations towards the company are the reference point for the opinions and evaluations they make. Watrick (1992) defines reputation as the sum of the individual's insights into the extent to which a company's operations meet the demands and expectations of its various stakeholders. Similarly, Waddock (2000) defines reputation as the perceived ability of a company to meet the expectations of its stakeholders.

The company has many stakeholder groups, such as customers (including consumers), employees, business partners, investors, media, public administration, local communities and so on, whose needs and expectations towards the company are different and often contradictory (Szwajca, 2014). Each of these groups evaluates the company from a different point of view, through their own interests, using different criteria (Pirez and Tres, 2018). As a result, a company can obtain multiple assessments, and each of them may be different. Therefore, the company may have not one, but many reputations, depending on the stakeholder group and its expectations. Table 1 shows the types of reputation with an indication of the specific stakeholder group and the dominant assessment criteria.

However, it should be noted that, despite the conflicts of interest of certain stakeholder groups, their opinions on the company are mutually determined. For example, a company's reputation as an employer can affect its reputation as a offerer and "supplier" of value or as a citizen. If the company treats its employees badly, it is perceived negatively by customers who may boycott the company's products; it may also be stigmatized by local communities and the media as unfair and unethical.

Customers/consumers are included in the key stakeholder groups of companies in all industries (B2B customers, B2C consumers) because their purchasing behavior and decisions (loyalty) determine the financial performance, capability and prospects of the company, and thus, the ability to meet the expectations of other groups (Zavyalova, et al., 2016; Kenny, 2014; Soleimani, et al., 2014; DickinsonDelaporte, et al, 2010; Walsh and Beatty, 2007). Customers who evaluate the company and its offer well are more willing to buy its products, are more loyal, recommend the company to others, thereby ensuring its high and stable income and profits, which affects:

- meeting the expectations of investors (high profit rate, stable development of the company and lower risk, good prospects for the future),

- meeting employees' expectations (stability and security of employment, attractive salaries, professional development opportunities),

- meeting the expectations of business partners (possibility of execution of profitable contracts, timely payments, chance for long-term cooperation). 
Table 1. Corporate reputations by stakeholder groups

(Source: Szwajca, 2016, p.65)

\begin{tabular}{|c|c|c|}
\hline Stakeholders' group & Assessment criteria & Company's reputation as: \\
\hline Customers / consumers & $\begin{array}{l}\text { - economic } \\
\text { - ethical } \\
\text { - legal }\end{array}$ & Offerer and "supplier" of value \\
\hline Business partners & $\begin{array}{l}\text { - economic } \\
\text { - } \text { organizational } \\
\text { - ethical }\end{array}$ & Business partner \\
\hline Investors & $\begin{array}{l}\text { - economic } \\
\text { - organizational }\end{array}$ & Market player \\
\hline Employees & $\begin{array}{l}\text { - economic } \\
\text { - } \text { organizational } \\
\text { - legal } \\
\text { - social } \\
\text { - ethical }\end{array}$ & Employer \\
\hline Media & $\begin{array}{l}\text { - organizational } \\
\text { - ethical }\end{array}$ & Generator and source of information \\
\hline Public administration & - legal & Holder of rights and obligations \\
\hline Local communities & $\begin{array}{l}\text { - social } \\
\text { - ethical }\end{array}$ & Citizen, member of the community \\
\hline
\end{tabular}

This way, customers directly influence the company's reputation as a market player, employer and business partner.

In addition, customers/consumers are keen to share their comments on the goods and services they buy, the level of service, the handling of complaints and so on, in online forums (Jin, et al., 2016; Viglia, et al., 2016; Pfeffer, et al., 2014), as well as through the activity of various consumer organizations (demonstrations, boycotts, lawsuits) or other social organizations.

This information reaches out to the media (traditional and modern) and, through them, to groups such as public administration, local communities and the general public. This way, customers contribute to creating a company's reputation as a generator and source of information, a holder of rights and obliga- tions and a citizen and member of the local community.

It should also be added that the opinions of these stakeholder groups also influence the perception of the company by investors, employees and business partners, and thus indirectly shape the reputation of the company as a market player, employer and business partner. The described dependencies are presented in Fig. 1.

Therefore, customers might be considered the main creators of reputation, as they can - to a large extent - directly and indirectly influence the opinions of other stakeholder groups. In this regard, identifying the needs and expectations of the new digital customer of the future from the point of view of the possibility of building a good reputation of the company seems particularly justified. 


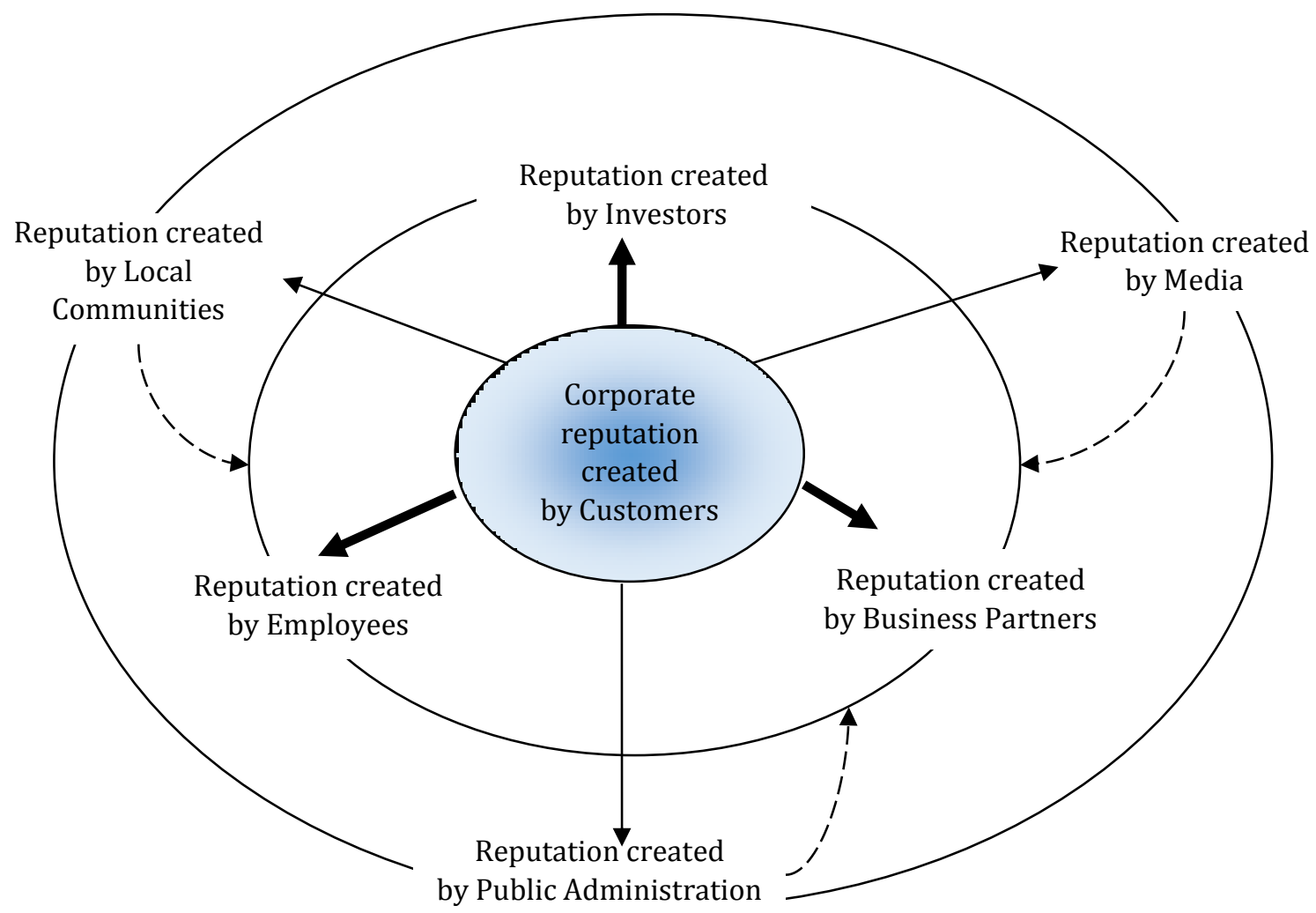

Figure 1. Customers as the main creators of the company's reputation

(Source: Own work)

\section{$3 \quad$ Purchasing behavior and personality profile of the digital customer}

A digital customer can be briefly defined as a purchaser using mobile devices (palmtop, notebook, smartphone, tablet, etc.) in their relations with offerers of goods and services in the market. A digital customer is also an e-customer who uses the Internet in almost all phases of the purchase process ${ }^{2}$. In the awareness-raising phase, that is, the search for a way to solve the problem, he may ask questions to specialists or other consumers on various online forums and platforms.

The Internet is especially useful in the second phase (search for information), as it gives unlimited possibilities of searching and accessing information in one place and time. The Internet is also extremely useful in the phase of comparing selection options, not only due to comparison engines, but also the possibility of getting to know the opinions of other users, for example, on discussion forums or in social media. After choosing an offer, the consumer can make a purchase without leaving home, but using the services of online shops offering convenient forms of delivery and payment. Finally, in the fifth phase (post-purchase behavior), consumers have the opportunity to express their views on the offer (positive or negative) on their blogs or other forums. They can also make a complaint using the relevant applications or online forms.

The use of digital mobile devices equipped with many applications, together with Internet access by customers, influences the change of shopping habits and behaviors, which have been and are the subject of many researches and analyses. The results of some of them presents Table 2 .

As the characteristics presented in Table 2 demonstrate, a digital customer is, first and foremost, a well-informed, more aware and independent buyer.

\footnotetext{
2 In the classic approach, the process involves five phases: awareness-raising, information search, comparison of alternatives, purchase, post-purchase behavior. See: Kotler, P., Keller, K.L. 2016. Marketing. Poznań: Dom Wydawniczy Rebis.
} 
Table 2. Behavior and shopping habits of digital customers according to the selected research results

(Source: Wojciechowska, 2018; Gieracz, 2014; www3, 2015)

\begin{tabular}{|c|c|c|}
\hline $\begin{array}{l}\text { ShoppingShow } 2014 \\
\text { research }\end{array}$ & $\begin{array}{c}\text { Media Vision Interactive research, } \\
\text { October } 2015\end{array}$ & $\begin{array}{l}\text { Customer 2020: } 3 \text { consumer trends that } \\
\text { will change the face of e-commerce, } 2018\end{array}$ \\
\hline $\begin{array}{l}\text { - } \text { awareness } \\
\text { - } \text { impatience } \\
\text { - convenience, } \\
\text { intuitiveness, comfort } \\
\text { - repeatability } \\
\text { - openness, pragmatism, } \\
\text { curiosity } \\
\text { - trends, fads, } \\
\text { changeability }\end{array}$ & $\begin{array}{l}\text { - } \text { information, } \\
\text { - } \text { multi-channel communications } \\
\text { - } \text { customer dialog } \\
\text { - } \text { setting standards } \\
\text { - lower customer tolerance } \\
\text { - lower loyalty } \\
\text { media (promotion), }\end{array}$ & $\begin{array}{l}\text { - well-informed, more aware } \\
\text { and autonomous } \\
\text { - impatient } \\
\text { - comfortable }\end{array}$ \\
\hline
\end{tabular}

This is not only due to the ability to access information on the Internet, but also due to the fact that the digital customer not only uses mobile devices to complete transactions, but also uses digital products, such as smart watches, home appliances, footwear, clothing and other products equipped with sensors to collect and process large amount of data. "Today, in a world where consumers can collect data themselves, customers are often better educated than sales representatives they do business with" (Meerman, 2015).

The second important feature of a digital customer's shopping behavior is their impatience. A digital customer appreciates the speed of access to information, making contact, learning all the details of the offer, completing the transaction, making payment and receiving the product. Therefore, if an application is too complicated, takes a lot of time, the website loads slowly and the content and procedures are unclear or incomprehensible, the customer quickly gets irritated and resigns from the offer.

Other characteristics of the digital buyer are convenience, intuitiveness and comfort. The user of a mobile device strives to minimize the effort and time associated with the purchase process. They want to be able to navigate freely through a website or application, easily find an offer, fill in a shopping cart and pay for it. The simpler, shorter and more readable the purchase procedure, the more often the consumer completes the transaction. As a result, a digital customer is willing to use the same tested websites, e-shops or applications - they are characterized by repeatability of behavior.

The influence of technological progress and fierce competition is constantly resulting in new solutions of augmented reality (e.g., related to 3D technology), new, more efficient applications. Digital customers keep a close eye on the latest technological developments, and they immediately test and use any solutions that improve their shopping experience. In this respect, they are open, interesting and pragmatic.

The desire to improve comfort and convenience means that customers compare brands not only with direct competitors, but rather with all the brands they use, regardless of the industry or product. The scope of comparisons concerns not only the product itself. It also includes many aspects of support, such as service, delivery, product testing, payment method, advertising and so on. Offerers should, therefore, focus not so much on the observation of direct competition as on the solutions used by the best brands that the customer uses. For example, if a clothing brand offers the possibility of projecting clothes in 3D, such solution can be successfully applied by a furniture brand. Contemporary consumers, therefore, compare clothing with furniture, cars with cosmetics, coffeehouses with travel agencies. This way, they become creators of new quality standards (www4, 2018). 
Digital customers expect high standards of quality and service, have many offers to choose from and, therefore, become less tolerant and forgiving to offerers. Any errors, mistakes, not to mention fraud or dishonest actions, are immediately stigmatized and criticized on Internet forums, in social media, as warnings to other consumers.

A digital customer is easily affected by trends, fads and the resulting variability. The number of emerging digital shopping solutions, e-shops and smart products is so high that consumers are not able to assimilate them all, they have to make constant choices for their own comfort and convenience. It affects the level of loyalty to a brand, store or producer.

By communicating through multiple channels with other Internet and social media users, digital customers have less confidence in information and advertising provided through traditional media. They trust the opinions and comments of other customers, organized in various discussion groups or brand fan clubs.

The use of mobile devices and the Internet while shopping affects not only the behavior and shopping habits of customers, but also their way of thinking, values and personality features. A digital customer, well informed, aware of their needs and rights, becomes an independent, determined, self-confident, more demanding and critical person. The digital customer is also characterized by courage, curiosity about novelties, high level of demand in terms of service and simplification of decisions (Persaud and Azhar, 2012; www5, 2014).

A digital customer is an independent individualist, striving to personalize everything (expressing their own otherness through unique objects), to create something unique on their own (Wódkowski, et al., 2014). Searches and develops their own unique way of life, which allows them to satisfy their individual needs and create e-customs (Fisk, 2014; Cold, 2013). They are also active and creative persons, who get involved in various projects and willingly respond to interesting initiatives in search of new, attractive experiences (Kotarbiński, 2015; Soopramanien, 2011). In terms of demographic characteristics, the digital customer is usually young, well-educated and rather affluent.

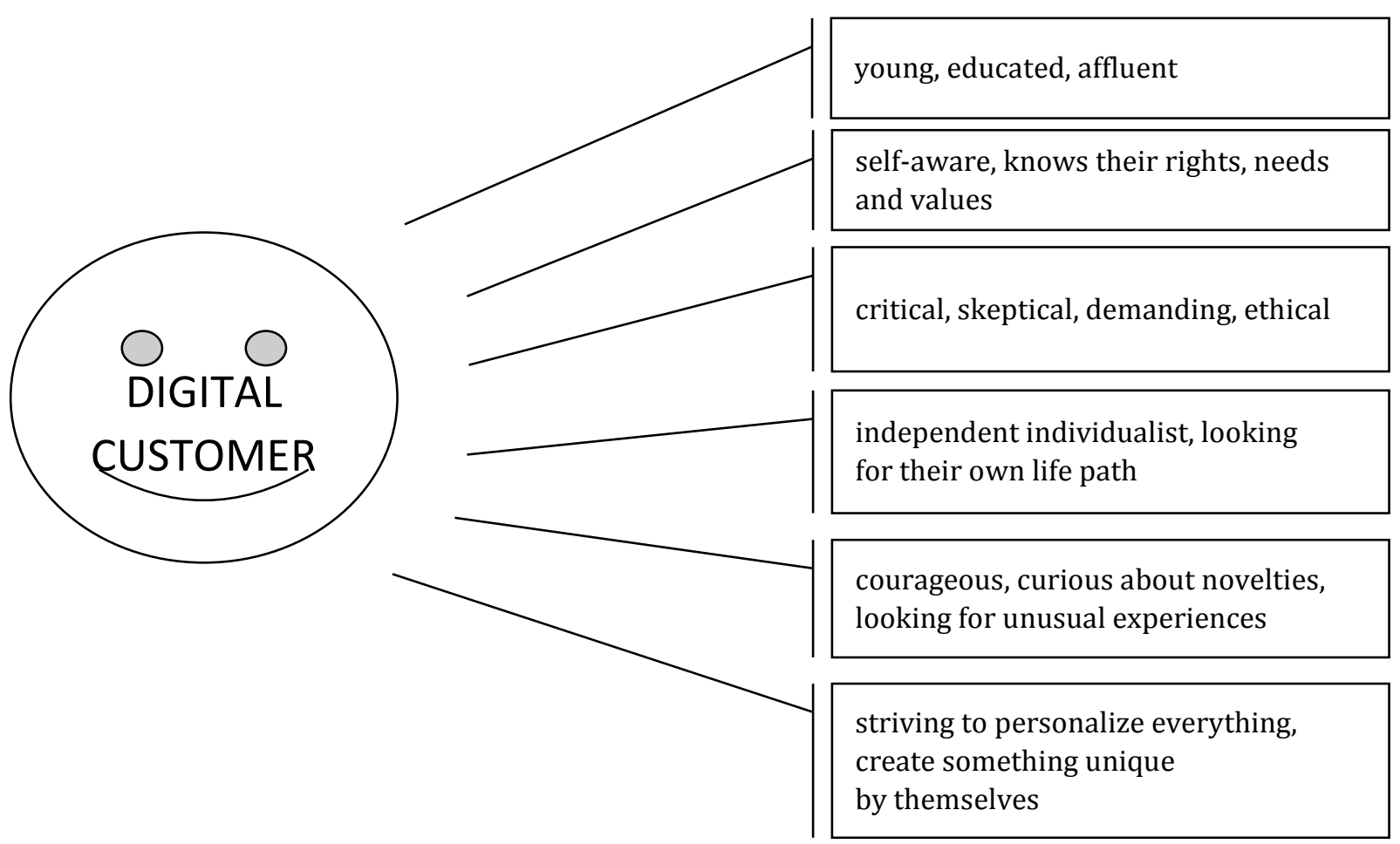

Figure 2 . The personality profile of a digital customer

(Source: Own work) 
A digital consumer feels better in the virtual world than in the real world; this is the world in which they build relationships with others, not only receiving content, but also editing, creating and sharing it, and trusting the opinions of other users (Behavior of digital customers on the web, http). According to psychologists, the development of digital technologies makes many people feel that the real and virtual worlds intertwine. These people are convinced that they need to be constantly connected to the Internet to function effectively in these conditions. Consequently, this can lead to some kind of addiction or nomophobia (no mobile phone phobia), that is, the fear of being out of cellular phone contact and Internet access. This is related to the fear that a lack of connection to the network will make it impossible to receive important information, get to know interesting offers, take advantage of exceptional opportunities. This is a syndrome called FOMO (fear of missing out), which is the fear that one might miss an opportunity for something. In the psychology of consumer behavior, this category of consumers has been called digitized (Grzeszak, 2013).

\section{$4 \quad$ Preferences and expectations of digital customers with regard to research}

In order to identify digital preferences and expectations of customers, the results of consumer opinion surveys conducted by KPMG consulting company in the second quarter of 2018 were analyzed. The study used the Six Pillars ${ }^{\mathrm{TM}}$ of Customer Experience method, developed by KPMG Nunwood UK experts, which identified six key factors determining consumers' willingness to recommend a given brand. These factors, called the pillars of consumer experience, are the following:

- reliability - keeping one's word; consistent implementation of promises and building trust towards the brand,

- problem solving - ability to solve crisis situations when using the company's products or services; effectiveness and speed of action in unforeseen situations, ability to admit to mistakes,

- expectations - understanding and meeting expectations; exceeding standard expectations,

- time and effort - removing unnecessary obstacles, difficulties and unnecessary bureaucracy, which enables the consumer to use the offer of a given brand as efficiently and easily as possible,

- personalization - the ability to understand individual needs of a customer and to deliver a product or service that meets their specific expectations,

- empathy - the ability to understand and respond adequately to a specific situation of a customer.

In accordance with the assumptions of the method, the role of the individual Six Pillars ${ }^{\mathrm{TM}}$ of Customer Experience in building positive customer experiences is as follows:

1) Basic pillars: reliability and problem solving: Build trust and respond effectively in crisis situations:

2) Intermediate pillars: expectations + time and effort: Stay in touch and simplify processes;

3) Distinguishing pillars: personalization + empathy Show that you know the needs, "anticipate" the questions and surprise positively.

The survey among Polish consumers was conducted using the CAWI (Computer-Assisted Web Interview) method on a sample of over 5000 respondents, representative of Polish residents aged over 16. The survey included 192 brands of companies from 9 sectors (leisure and entertainment, electricity and gas suppliers, catering, logistics, media and telecommunications, travel, food retail, non-food retail, financial services).

Analyses in 2018 showed that individual pillars are of similar importance for Polish consumers as in countries with the most developed consumer markets. In Poland, as well as in the 20 countries surveyed on 4 continents, the pillars "Reliability" and "Personalization" have the most important impact on customer feedback on brands (Fig. 3). 


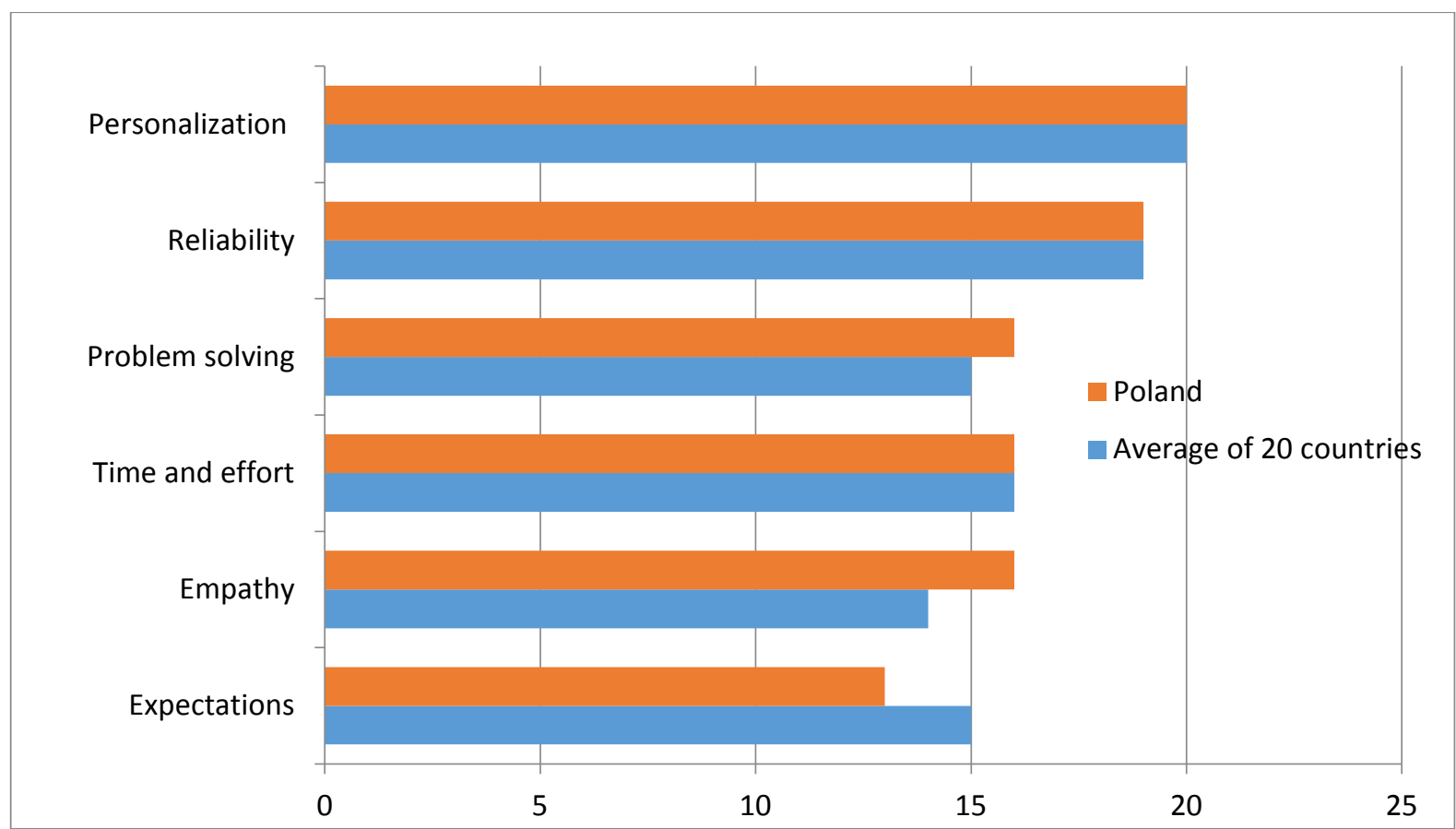

Figure 3. Importance of the Six Pillars ${ }^{\mathrm{TM}}$ of the Customer Experience in Poland and 20 other countries in 2018

(Source: Own study based on: www6, 2019)

As the figure shows, the importance of these two pillars has been equally assessed in Poland and other countries. The biggest discrepancies in the assessments concern the pillars: "Expectations" and "Empathy". "Expectations" are less influential in shaping Polish consumers' opinions on brands than in other countries surveyed, while "Empathy" is more influential in shaping Polish consumers' opinions on brands.

Fig. 4 shows the importance of particular pillars for the assessment of brands for Polish consumers in 2017 and 2018. In 2018, the importance of the "Personalization" and "Reliability" pillars increased in comparison to 2017, with a greater increase in "Reliability". The role of the other pillars has slightly increased ("Time and effort", "Empathy") or remained unchanged ("Problem-solving"); only for "Expectations" it has decreased.

The results of the presented research allow for some conclusions to be drawn about the impact of digitization on the change of preferences and expectations of customers (especially consumers) towards the company and its offer. The greatest importance at- tached to reliability can be attributed to the following effects of digitization.

First, digitization introduces a new communication channel and a new way of establishing and maintaining customer relationships. Customers expect information and service levels to be consistent across channels - if a company communicates different and particularly conflicting messages across channels, it loses reliability and trust.

Second, digitization is changing the approach to competence and the content of the information provided by the company. Digital customers, being more aware of their rights, well-educated, better informed, have increasing demands on the quality of the information provided by the company. They do not trust brands that present incomplete, unclear or not entirely true information about the product, its values, components, production process, price, hide additional fees, place unfavorable provisions in contracts in small print and so on. They appreciate more and more the competence of sales and service personnel, who can answer difficult questions and give honest advice, for example, suggesting that it is more advantageous to buy a given product in a set. 


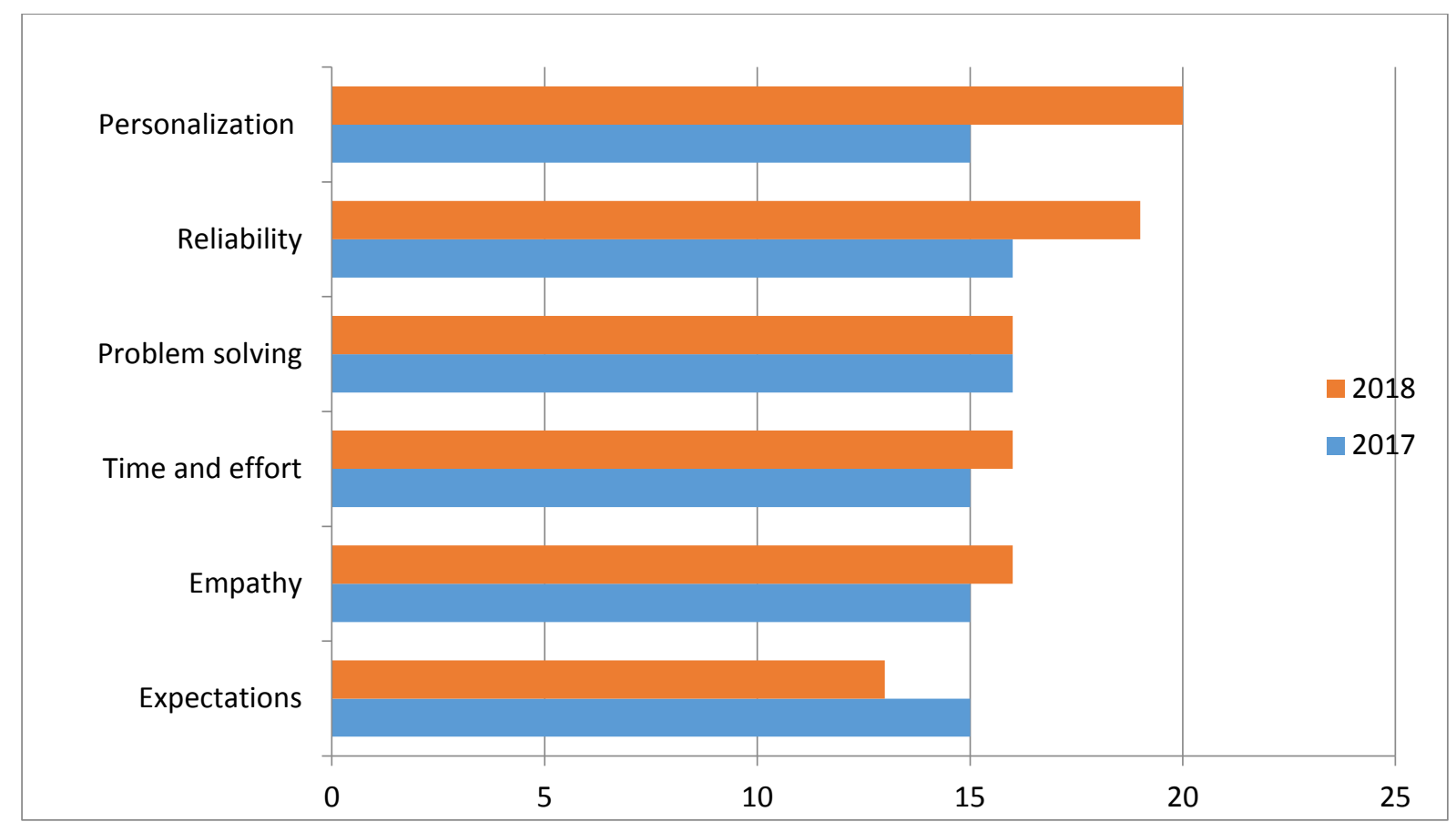

Figure 4. Importance of the Six Pillars ${ }^{\mathrm{TM}}$ of the Customer Experience in Poland in 2017 and 2018 (Source: Own study based on: www6, 2019)

Third, digitization is a carrier of social change relating to corporate social responsibility. Digital consumers are more environmentally aware and sensitive to environmental problems. Therefore, they pay special attention to the composition of the product, the origin of raw materials, production technology, biodegradable packaging, company's involvement in pro-social initiatives and so on.

Fourth, digital customers are more sensitive to the protection of personal data, especially after the introduction of the GDPR. Any abuse by the company in this regard may adversely affect their confidence in the company.

Fifth, in the digital world, customers shape their opinions about the company and its offerings, not only through their own experiences, but also through the comments and opinions of friends whom they generally trust more. A negative opinion of a single consumer can quickly spread across the web and destroy the brand's reputation.

The second pillar in terms of importance for building positive experiences with a brand is personalization, which - for the customer - means that the company knows them and can provide them with the best offer. Such attitude is also, to a large extent, the result of digitization.
Digitization enables the company to obtain many valuable information about its customers, both personal (i.e., age, gender, address, profession, etc.), as well as about their interests, preferences, purchase decisions and so on. Traces left by consumers in the digital world, for example, in the form of the socalled cookies or data placed on social media portals, make it possible to build a precise, individual profile of each of them.

With this information, the company can better understand the customer's needs, its financial capabilities, decision criteria, preferred communication channels, payment methods and so on, and is able to prepare an adequate, individual offer. It is worth noting that the effective use of this information requires advanced data analytics, as well as the use of artificial intelligence systems. However, effective personalization in the digital world is severely hindered by the introduction of legal regulations, especially GDPR, namely:

- the obligation to inform the consumer of the individual profiling,

- the consumer's right to request the erasure of personal data held by a given brand,

- the consumer's right to request the transfer of their personal data to another company. 
Therefore, digital customers who expect a personalized offer and a personalized service, who know their rights, may consent to the processing of their data. There is also a very important feedback - the better the experience offered by a brand to a consumer, the more likely consumers are to share their data with that brand.

It should be noted that companies recognize the specificity of digital customers and increasingly take their needs and expectations into account in their investment plans. It stems, among others, from the Accenture Technology Vision 2019 report. Technology Vision is an annual report that forecasts the key technology trends that will attract the most investment in the next three years.

The 2019 edition of the report was created on the basis of surveys conducted among over 6600 executives from 27 countries, including Poland for the first time (www7, 2019). The report shows that over 63\% of companies in the world and $60 \%$ in Poland intend to invest in artificial intelligence solutions within the next year, and the overriding goal of these investments is to create additional value for customers and provide them with personalized experience.

\section{Summary}

Corporate reputation, understood as the opinion of various stakeholder groups on its activities, is formulated on the basis of an assessment of the degree to which their expectations about the company have been met. Customers are one of the key stakeholder groups that create the reputation of the company as an offerer and "supplier" of value to the customer. This is also a group of stakeholders that has a significant impact on building the reputation of a company as a market player, employer, business partner, as well as a generator and source of information, a holder of rights and obligations and a citizen.

The financial results and development prospects of a company depend on purchase decisions and market behaviors, which shape the possibilities of meeting the expectations of such stakeholder groups as investors (profits), employees (salaries and bonuses), business partners (profitable contracts). Opinions, comments and the activity of customers /consumers (e.g., boycotts) influence the attitudes of the media, public administration, local communities towards the company, which indirectly influences the actions and behavior of investors, employees and business partners.

The development of mobile technologies and the progressive digitization of almost all areas of life lead to the development of a new type of customer a digital customer. Digitization affects not only the behavior and buying habits of the customer, but also the personality profile of the customer. Purchasing behavior of a digital customer is characterized by: high awareness, independence, impatience, search for comfort and convenience, changing preferences, lower loyalty to the brand or offerer, greater skepticism and less tolerance to errors and mistakes.

In terms of personality, a digital client is a person aware of themselves, their rights, needs and values, active and creative, open, more critical and demanding. They are independent individualists, bold, curious about new products, striving to personalize everything and wanting to create something unique on their own.

In the light of the latest research conducted by KPMG consulting agency, the preferences and expectations of digital customers in Poland and the 20 highly developed countries surveyed are focused on two pillars: reliability and personalization, whose importance has increased in the recent years.

This is very important information for companies in the context of building and maintaining a positive reputation, because reliability is one of the foundations of reputation. It seems that the indicated pillars (especially personalization) are noticed and considered by the management of a significant number of enterprises.

The Accenture Technology Vision 2019 report shows that over $60 \%$ of companies in the world and in Poland intend to invest in artificial intelligence solutions within the next year, and the overriding goal of these investments is to create additional value for customers and provide them with personalized experiences. 
[1] Dickinson-Delaporte, S., Beverland, M., Lindgreen, A., 2010. Building Corporate Reputation with Stakeholders: Exploring the Role of Message Ambiquity for Social Marketers. European Journal of Marketing, 44(11/12), pp.1856-1874, DOI: https://doi.org/10.1108/03090561011079 918.

[2] Dowling, G.R., 2016. Defining and Measuring Corporate Reputations. European Management Review, 13(3), pp.207-223, DOI: http://dx.doi. org/10.1111/emre.12081.

[3] Fisk, P., 2014. Geniusz konsumenta. Prowadzenie firmy skoncentruj na oczekiwaniach nabywcy (The Genius of the Cosumer. Keep the Company Focused on the Expectations of the Buyer). Warsaw: Publishing House a Wolters Kluwer Business.

[4] Gieracz, M., 2014. Zwyczaje zakupowe "zniecierpliwionych" klientów (Shopping Habits of "Impatient" Customers). Marketer+. Przewodnik po marketingu, wrzesień-październik, 3(14).

[5] Grzeszak, A., 2013. E-konsumenci i cyfrowy biznes (E-consumers and Digital Business). Polityka, 25.06.2013.

[6] Jin, J., Ji, P., Kwong, C.K., 2016. What Makes Consumers Unsatisfied with Your Products: Review Analysis at a Fine-grained Level. Engineering Applications of Artificial Intelligence, 47(C), pp.38-48, DOI: https://doi.org/10.1016/ j.engappai.2015.05.006.

[7] Kenny, G., 2014. Five Questions to Identify Key Stakeholders. Harvard Business Review, March.

[8] Kotarbiński, J., 2015. Kupujemy już inaczej (We Buy Differently). Marketing $w$ praktyce (Marketing in Practice), No. 4, pp.34-36.

[9] Kotler, Ph., Keller, K.L., 2016. Marketing. Poznań: Dom Wydawniczy Rebis.

[10] Krzepicka, A., 2016. Współczesny konsument konsument digitalny (Contemporary Consumer Digital Consumer). Studia Ekonomiczne, No. 225, pp.207-214.

[11] Meerman, D.S., 2015. Nie przeszkadzaj klientowi $w$ zakupach (Do not Disturb the customer in Shopping). Warszawa: Wydawnictwo Naukowe PWN.
[12] Persaud, A., Azhar, I., 2012. Innovative Mobile Marketing via Smartphones: Are Consumer Ready? Marketing Intelligence \& Planning, Vol. 30, pp.418-443, DOI: 10.1108/0263450121123 1883.

[13] Pfeffer, J., Zorbach, T., Carley, K.M., 2014. Understanding Online Firestorms: Negative Word-of-Mouth Dynamics in Social Media Networks. Journal of Marketing Communications, 20(1-2), pp.117-128. DOI: 10.1080/13 527266.2013 .797778 .

[14] Pires, V., Trez, G., 2018. Corporate Reputation: A Discussion on Construct Definitionand Measurement and its Relation to Performance. Revista de Gestão, 25(1), pp.47-64, DOI: https://doi.org /10.1108/REGE-11-2017-005.

[15] Soleimani, A., Schneper, W.D., and Newburry, W., 2014. The Impact of Stakeholder Power on Corporate Reputation: A Cross-Country Corporate Governance Perspective. Organization Science, 25 (4), pp.991-1008, DOI: https://doi.org/ 10.1287/orsc.2013.0889.

[16] Soopramanien, D., 2011. Conflicting Attitudes and Scepticism Towards Online Shopping: the Role of Experience. International Journal of Consumer Studies, 35(3), pp.338-347, DOI: https://doi.org/10.1111/j.1470-6431.2010.0094 5.x.

[17] Szwajca, D., 2014. Zarządzanie reputacją przedsiębiorstwa wobec sprzeczności oczekiwań interesariuszy (Managing the Company's Reputation against Conflicting Expectations of Stakeholders). Studia Ekonomiczne, No. 202, pp.9099.

[18] Szwajca D., 2016. Management of the Company's Reputation. Building and Restoring Stakeholder Confidence. Warszawa: CeDeWu, p.65.

[19] Waddock, S., 2000. The Multiple Bottom Lines of Corporate Citizenship: Social Investing, Reputation and Responsibility Audits. Business \& Society Review, 105(3), pp.323-345, DOI: https://doi.org/10.1111/0045-3609.00085.

[20] Walsh, G. and Beatty, S.E., 2007. CustomerBased Corporate Reputation of a Service Firm: Scale Development and Validation. Journal of the Academy of Marketing Science, 35 (1), pp.127-143, DOI: 10.1007/s11747-007-0015-7. 
[21] Watrick, S.L., 1992. The Relationship between Intense Media Exposure and Change in Corporate Reputation. Business and Society, 31(1), pp.33-49, DOI: https://doi.org/10.1177/00076 5039203100104.

[22] Wojciechowska, E., 2018. Klient 2020: 3 trendy konsumenckie, które zmienią oblicze ecommerce (Client 2020: 3 Consumer Trends that Will Change the Face of e-Commerce). [online] Available at: https://www.e-point.pl/blog/klient2020-3-trendy-konsumenckie-ktore-zmienia-obli cze-e-commerce [Accessed 24 April 2019].

[23] Wódkowski, A., Kociankowski, M., Gawlik, K., 2014. Nowe nurty konsumenckie (New Consumer Trends). Harvard Business Review Polska, No. 140.

[24] Viglia, G., Minazzi, R., and Buhalis, D., 2016. The Influence of e-Word-of-Mouth on Hotel Occupancy Rate. International Journal of Contemporary Hospitality Management, 28 (9), pp.2035-2051, DOI: https://doi.org/10.1108/ IJCHM-05-2015-0238.

[25] Zavyalova, A., Pfarrer, M.D., Reger R.K., and Hubbard, T.D., 2016. Reputation as a Benefit and a Burden? How Stakeholders' Organizational Identification Affects the Role of Reputation Following a Negative event. Academy of Management Journal, 59 (1), pp.253-276, DOI: https://doi.org/10.5465/amj.2013.0611.

[26] www1, 2018. Raport Interaktywnie.com: eCommerce (Interactive Report.com:eCommerce). 2018. [online] Available at: $<$ https://eizba.pl/wpcontent/uploads/2018/07/rap ort_ecommerce.pdf> [Accessed 15 May 2019].

[27] www2, 2016. W 2020 klienci będą się obsługiwać samodzielnie za pośrednictwem botów i VR - wynika z badania Oracle (In 2020, Customers
Will Be Able to Operate Independently Through Bots and VR - According to an Oracle Study), 2016, [online] Available at: <http://ccnews .pl/2016/12/13/w-2020-klienci-beda-sie-obslugi wac-samodzielnie-za-posrednictwem-botow-i-vr -wynika-z-badania-oracle/> [Accessed 17 March 2019].

[28] www3, 2015. How Digital is Changing Consumer Behaviour, 2015. [online] Available at: $<$ https://www.mediavisioninteractive.com/social -media/how-digital-is-changing-consumer-beha viour/> [Accessed 17 May 2019].

[29] www4, 2018. Kto tworzy cyfrowego konsumenta? 29/03/2018. Kongres Konsument 2018 (Who Creates a Digital Consumer? 29/03/2018. Consumer Congress 2018). [online] Available at: $<\mathrm{https}$ ://kpf.pl/kto-tworzy-cyfrowego-konsumen ta/> [Accessed 17 April 2019].

[30] www5, 2014. ShoppingShow 2014. Konsument Digitalny a wirtualna rzeczywistość. Przewodnik po raportach o digitalizacji rynku (Digital Consumer and Virtual Reality. Guide to Reports on Market Digitization). [online] Available at: $<$ http://www.shoppingshow.pl $>$ [Accessed 17 April 2019].

[31] www6, 2019. [Cyfrowy] klienta nasz pan. Raport KPGM, 2019 ([Digital] Customer our Master. KPGM Report, 2019). [online] Available at: <https://assets.kpmg/content/dam/kpmg /.../pl-Raport-KPMG-Cyfrowy-klient-nasz-pan. $p d f>$ [Accessed 17 March 2019].

[32] www7, 2019. Accenture Technology Vision 2019. [online] Available at: <https://www. accenture.com/pl-pl/insights/technology/techno logy-trends-2019> [Accessed 12 May 2019]. 